\title{
Perspectives on the L2 Phrasicon
}




\section{SECOND LANGUAGE ACQUISITION}

Series Editors: Professor David Singleton, University of Pannonia, Hungary and Fellow Emeritus, Trinity College, Dublin, Ireland and Associate Professor Simone E. Pfenninger, University of Salzburg, Austria

This series brings together titles dealing with a variety of aspects of language acquisition and processing in situations where a language or languages other than the native language is involved. Second language is thus interpreted in its broadest possible sense. The volumes included in the series all offer in their different ways, on the one hand, exposition and discussion of empirical findings and, on the other, some degree of theoretical reflection. In this latter connection, no particular theoretical stance is privileged in the series; nor is any relevant perspective - sociolinguistic, psycholinguistic, neurolinguistic, etc. - deemed out of place. The intended readership of the series includes final-year undergraduates working on second language acquisition projects, postgraduate students involved in second language acquisition research, and researchers, teachers and policymakers in general whose interests include a second language acquisition component.

All books in this series are externally peer-reviewed.

Full details of all the books in this series and of all our other publications can be found on http://www.multilingual-matters.com, or by writing to Multilingual Matters, St Nicholas House, 31-34 High Street, Bristol BS1 2AW, UK. 


\title{
Perspectives on the L2 Phrasicon
}

The View from Learner Corpora

\author{
Edited by \\ Sylviane Granger
}


DOI https://doi.org/10.21832/GRANGE4856

Library of Congress Cataloging in Publication Data

A catalog record for this book is available from the Library of Congress.

Names: Granger, Sylviane, editor.

Title: Perspectives on the L2 Phrasicon: The View from Learner Corpora/

Edited by Sylviane Granger.

Description: Bristol, UK; Blue Ridge Summit, PA: Multilingual Matters, 2021. | Series: Second Language Acquisition: 148 | Includes

bibliographical references and index. | Summary: 'This is the first book to investigate the field of phraseology from a learner corpus perspective. It includes cutting-edge studies which analyse a wide range of multiword units and extensive learner corpus data to provide the reader with a comprehensive theoretical, methodological and applied perspective onto L2 use in a wide range of situations' - Provided by publisher.

Identifiers: LCCN 2021010571 (print) | LCCN 2021010572 (ebook) | ISBN 9781788924856 (hardback) | ISBN 9781788924863 (pdf) | ISBN 9781788924870 (epub) | ISBN 9781788924887 (kindle edition)

Subjects: LCSH: Language and languages - Study and teaching - Foreign speakers. | Phraseology - Study and teaching. | Second language acquisition.

Classification: LCC P53.6123 .P48 2021 (print) | LCC P53.6123 (ebook) | DDC $418.0071-\mathrm{dc} 23$

LC record available at https://lccn.loc.gov/2021010571

LC ebook record available at https://lccn.loc.gov/2021010572

British Library Cataloguing in Publication Data

A catalogue entry for this book is available from the British Library.

ISBN-13: 978-1-78892-485-6 (hbk)

Multilingual Matters

UK: St Nicholas House, 31-34 High Street, Bristol BS1 2AW, UK.

USA: NBN, Blue Ridge Summit, PA, USA.

Website: www.multilingual-matters.com

Twitter: Multi_Ling_Mat

Facebook: https://www.facebook.com/multilingualmatters

Blog: www.channelviewpublications.wordpress.com

Copyright (C) 2021 Sylviane Granger and the authors of individual chapters.

All rights reserved. No part of this work may be reproduced in any form or by any means without permission in writing from the publisher.

The policy of Multilingual Matters/Channel View Publications is to use papers that are natural, renewable and recyclable products, made from wood grown in sustainable forests. In the manufacturing process of our books, and to further support our policy, preference is given to printers that have FSC and PEFC Chain of Custody certification. The FSC and/or PEFC logos will appear on those books where full certification has been granted to the printer concerned.

Typeset by Riverside Publishing Solutions. Printed and bound in the UK by the CPI Books Group Ltd.

Printed and bound in the US by NBN. 